\title{
Fluorescence in situ hybridization of chromosome 17 polysomy in breast cancer using thin tissue sections causes the loss of CEP17 and HER2 signals
}

\author{
HUIYONG JIANG $^{1}$, XIAOYAN BAI ${ }^{2}$, TONG ZHAO ${ }^{2}$, CHENG ZHANG $^{1}$ and XUEFENG ZHANG ${ }^{1}$ \\ ${ }^{1}$ Department of General Surgery, General Hospital of Shenyang Military Area Command, Shenyang, \\ Liaoning $110840 ;{ }^{2}$ Department of Nephrology, Nanfang Hospital and Guangdong Provincial \\ Institute of Nephrology, Guangzhou, Guangdong 510515, P.R. China
}

Received April 8, 2014; Accepted July 15, 2014

DOI: $10.3892 /$ or.2014.3402

\begin{abstract}
Human epidermal growth factor receptor 2 (HER2 gene) and chromosome 17 polysomy are associated with breast cancer prognosis, chemotherapy and hormone therapy. HER2 gene analysis using fluorescence in situ hybridization (FISH) with $4-\mu \mathrm{m}$ sections assuming a nuclear diameter of $6 \mu \mathrm{m}$ caused the loss of genetic DNA. Using intact whole nuclei FISH (WNFISH) and thin tissue section FISH (TTFISH), 109 cases of invasive breast cancer were examined to observe correlations among HER2 gene amplification, CEP17 polysomy and the HER2/CEP17 ratio. The results showed significant differences in the mean copy number of HER 2 and the HER2/CEP17 ratios between the WNFISH and TTFISH groups. No significant differences were observed in HER2 amplified, equivocal and non-amplified HER2 samples. Thirty-seven cases of CEP17 polysomy and 72 cases of non-polysomy were detected by WNFISH. Twenty-nine cases of CEP17 polysomy and 72 cases of non-polysomy were detected by TTFISH. Significant differences were observed between the two methods using the McNemar test $(\mathrm{P}=0.039)$. In conclusion, detection of chromosome 17 polysomy in breast cancer with fluorescence in situ hybridization using thin tissue sections may cause the loss of CEP17 and HER2 signals.
\end{abstract}

\section{Introduction}

Human epidermal growth factor receptor 2 (HER2), initially identified in a rat glioblastoma model (1), is a transmembrane receptor with tyrosine kinase activity. The HER 2 gene encodes

Correspondence to: Dr Xuefeng Zhang, Department of General Surgery, General Hospital of Shenyang Military Area Command, No. 83 Wenhua Road, Shenhe, Shenyang, Liaoning 110840, P.R. China

E-mail: huiyongj1210@126.com

Key words: breast cancer, whole nuclei, fluorescence in situ hybridization, HER2 gene a $185-\mathrm{kDa}$ receptor tyrosine kinase involved in the regulation of cell growth, survival and differentiation.

HER2 gene amplification and associated protein overexpression occur in 10-30\% of primary breast cancers (2-4). HER2 gene amplification by fluorescence in situ hybridization (FISH) and protein overexpression by immunohistochemistry (IHC) are associated with poor prognosis and reduced disease-free survival (5-7). Many new drugs are in early developmental stages or preclinical trials, including those directed at the HER 2 receptor, as well as those targeting downstream effectors and signaling pathways (8).

Trastuzumab-based therapy (9) is indicated for patients with HER2 overexpression or amplification. The American Society of Clinical Oncology (ASCO)/College of American Pathologists (CAP) guidelines for HER2 assays recommend two algorithms for performing IHC and FISH $(9,10)$. Based on the ASCO/CAP definition, $14.7 \%$ of breast carcinomas exhibit HER2 genetic heterogeneity. Clinical trials using dualor single-color FISH or chromogenic in situ hybridization (CISH) for HER2 gene copy number assessment successfully identified patients that benefited from trastuzumab therapy. However, systems assessing the HER2/CEP17 ratio may provide a more accurate evaluation of $H E R 2$ amplification than single probe systems (11). These claims are based on the fact that $8 \%$ of breast cancers show increased copy numbers of CEP17 by FISH (i.e., average CEP17 >3.0/nucleus), which represent chromosome 17 polysomy $(9,12,13)$.

Abnormalities of chromosome 17 are important molecular genetic events in breast cancer (14). Several important oncogenes (15), including HER2, TOP $2 A$ and $T A U$, tumor-suppressive genes $p 53, B R C A 1$ and $H I C-1$, as well as DNA double-strand break repair and recombination gene $R D M 1$, play an essential role in the development and progression of breast cancer. CEP17 polysomy is a major aberration, which is frequently identified in $20-40 \%$ of invasive breast carcinomas (16). A high HER2 gene copy number associated with polysomy 17 is a contributing factor in HER2 protein overexpression $(17,18)$. Findings of recent studies (19) have also shown that chromosome 17 polysomy is associated with HER2 gene expression, prognosis and sensitivity to chemotherapy in patients with breast cancer. However, in 


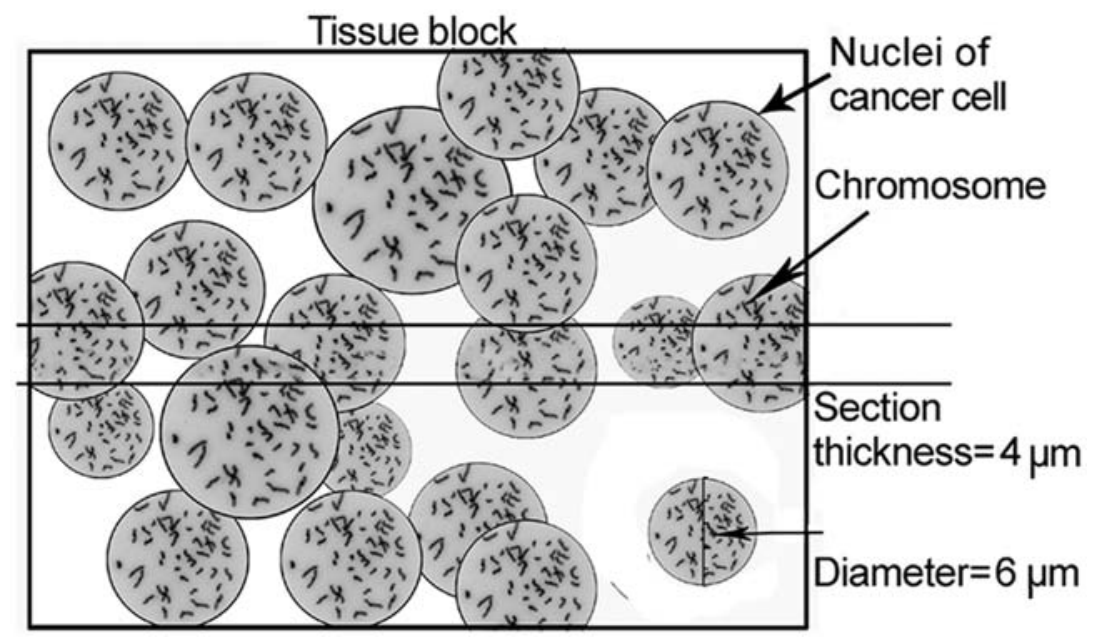

Figure 1. Design hypothesis. This diagram depicts that $4-\mu \mathrm{m}$ sections would cause the loss of genetic DNA, resulting in the detection error when performing FISH. FISH, fluorescence in situ hybridization.

previous studies, no effect of polysomy 17 on HER2 protein expression was identified (16). Instead, it only affected a small group of cases $(20,21)$. Additionally, the FISH algorithm may not identify positive IHC cases, if polysomy 17 affected the IHC score (9). As a result, the accurate assessment of HER2 status and chromosome 17 polysomy is of great importance in screening patients for trastuzumab therapy $(22,23)$.

In the HER 2 gene analysis and chromosome 17 amplification, FISH was performed using 4- $\mu$ m paraffin sections $(12,23-25)$. FISH conducted with thin tissue sections leads to the underestimation of the true chromosome copy number in various types of cancer (26). In this study it was hypothesized that the 4- $\mu \mathrm{m}$ sections caused DNA loss resulting in detection bias (Fig. 1). In the $4-\mu \mathrm{m}$ serial breast cancer paraffin sections, the same nuclei were sectioned twice and appeared in two adjacent sections (Fig. 2). The disruption of nuclear integrity may lead to an inaccurate estimate of gene copy numbers with thin tissue sections. Therefore, in the present study FISH with intact nuclei was performed to test the detection bias using thin tissue sections. In total, 109 cases of invasive breast cancer were examined for the correlation between $H E R 2$ gene amplification, CEP17 polysomy and HER2/CEP17 ratio.

\section{Materials and methods}

Case selection. In total, 109 patients (aged 33-83 years; median age, 49.5 years) diagnosed with invasive ductal carcinoma of breast at the General Hospital of Shenyang Military Area Command (Shenyang, China) between 2010 and 2011, were selected for a retrospective study. HER2 gene status was evaluated in the 109 formalin-fixed paraffin-embedded (FFPE) tissues by thin tissue section FISH (TTFISH) and whole nuclei FISH (WNFISH) with the nuclei extracted from the FFPE tissue blocks.

The present study was approved by the Ethics Committee of Shenyang General Hospital.

Extraction of whole nuclei. A stained section of each tumor sample was prepared from blocks to confirm the diagnosis. Representative tumor areas were then selected for extraction of the nuclei. Four tissue sample cores were collected from each specimen using a blunt core needle of $0.6 \mathrm{~mm}$ diameter. The needle was part of a Manual Arrayer (Beecher Instruments, Silver Spring, MD, USA) that was pushed through the entire paraffin tissue block. The collected tissue core was then forced into a $1.5-\mathrm{ml}$ polypropylene microcentrifuge tube.

Xylene $(1.0 \mathrm{ml})$ was added to the tube twice, each time for $20 \mathrm{~min}$ under light vibration, followed by the addition of $1.0 \mathrm{ml}$ of dehydrated ethanol twice, each time for $3 \mathrm{~min}$ under light vibration. One milliliter each of 80,70 and $50 \%$, respectively, ethanol was added into the tube, for 3 min under light vibration. The ethanol was discarded and the tube was dried at $45^{\circ} \mathrm{C}$ for $10 \mathrm{~min}$ for the remaining ethanol to evaporate. Enzymatic digestion was then performed using $300 \mu \mathrm{l}$ of freshly prepared proteinase $\mathrm{K}$ solution $[0.01 \%$ proteinase $\mathrm{K}, 30 \mathrm{~m}$ Anson-U/mg, in $0.05 \mathrm{~mol} / 1$ Tris-hydroxymethyl aminomethane hydrochloride (pH 7.0), $0.01 \mathrm{~mol} / \mathrm{l}$ ethylenediaminetetraacetic acid disodium salt, and $0.01 \mathrm{~mol} / 1$ sodium chloride] to the microcentrifuge tube. The specimen was then incubated at $37^{\circ} \mathrm{C}$ for $2 \mathrm{~h}$. The sample was vortexed for $3 \mathrm{sec}$ at 20 -min intervals during incubation to facilitate enzymatic digestion.

The mixture was vibrated and centrifuged at 1,000 rpm for $5 \mathrm{sec}$ to deposit the tissue mass. The nuclear suspension was extracted using a pipette. The nuclei were washed by resuspension in $100 \mu \mathrm{l}$ of phosphate-buffered saline (PBS) and vortexed. The PBS solution was removed and the nuclei were fixed by resuspension twice in freshly prepared fixative (3 parts methanol + 1 part glacial acetic acid) and vortexed. The fixative was removed and the nuclei were resuspended in $100 \mu \mathrm{l}$ of distilled water. Cell density was calculated on a cell-calculating plate and adjusted to $1 \times 10^{4} / \mu 1$ using distilled water.

The pretreated nuclear suspension $\left(1 \times 10^{4} / \mu \mathrm{l}\right)$ was pipetted onto poly-L-lysine-coated slides. The slides with cells were heated at $65^{\circ} \mathrm{C}$ for $1 \mathrm{~h}$ and the nuclei were ready for subsequent experiments after air drying.

WNFISH. WNFISH analysis was evaluated using a commercially available FDA-approved PathVysion HER2/neu DNA Probe kit (Abbott-Vysis, Downers Grove, IL, USA). The hybridization mixture included a centromere 17-specific spectrum 


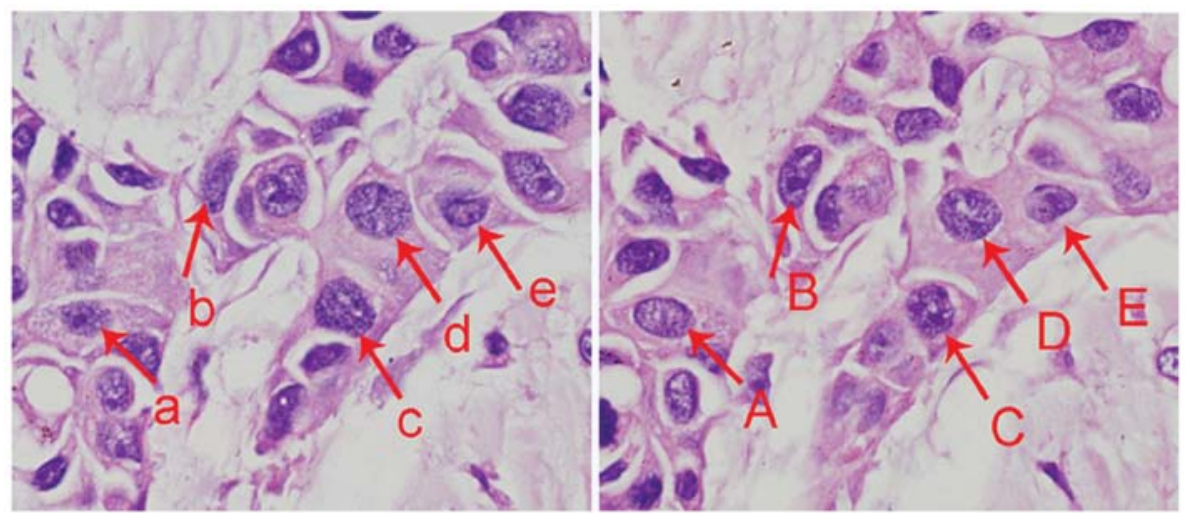

Figure 2. Two 4- $\mu \mathrm{m}$ serial sections of paraffin-embedded breast carcinoma tissue. The same nuclei (a-A, b-B, c-C, d-D and e-E) appear in the adjacent tissue sections.

with green-labeled DNA probe and HER2/neu-specific spectrum with an orange-labeled DNA probe.

The whole nuclei slides were dried in a $65^{\circ} \mathrm{C}$ oven for $1 \mathrm{~h}$, fixed with methanol-glacial acetic acid (3:1) for $1 \mathrm{~h}$. After air drying, the slides were placed in citrate buffer ( $\mathrm{pH} 6.0)$ and incubated for $10 \mathrm{~min}$ in a microwave oven, transferred to freshly prepared $0.4 \%$ pepsin solution $(0.16 \mathrm{~g}$ pepsin; $2,850 \mathrm{U} / \mathrm{mg}$ solid; in $40 \mathrm{ml}$ of $0.9 \%$ sodium chloride, $\mathrm{pH} 1.5$ ) and dehydrated through a series of graded ethanol. After dehydration, $10 \mu \mathrm{l} H E R 2 / \mathrm{CEN}-17$ probe mix was applied to the tissue and covered with a coverslip. The sections were placed in a HYBrite instrument, denatured at $82^{\circ} \mathrm{C}$ for $10 \mathrm{~min}$, and hybridized at $45^{\circ} \mathrm{C}$ for $16 \mathrm{~h}$. After hybridization the slides were washed in stringent wash buffer briefly at room temperature, and then in a $65^{\circ} \mathrm{C}$ hot solution for $10 \mathrm{~min}$. The slides were dehydrated, air-dried and counterstained with diamidinophenylindole.

The samples were analyzed under a x100 oil immersion objective using an Olympus BX-61 fluorescence microscope (Olympus, Japan) with appropriate filters.

Thin tissue section FISH (TTFISH). A 4- $\mu \mathrm{m}$ section of each tumor sample was prepared from blocks for thin-tissue FISH analysis. FISH was performed using the same HER2 FISH kit as for WNFISH. The section was treated by the Paraffin Pretreatment Reagent I (Gene Tech Company 02J02-032), according to the manufacturer's instructions. Following deparaffinization and rehydration, the slides were pretreated in hot $\left(95^{\circ} \mathrm{C}\right)$ 2-(N-morpholino)ethanesulfonic acid (MES) buffer for $10 \mathrm{~min}$ followed by a cooling step and pepsin digestion at room temperature for $10 \mathrm{~min}$. After dehydration, the section was subjected to similar treatment as in WNFISH. Breast cancer samples with known HER2 gene amplification served as positive controls.

Evaluation of HER2 gene amplification and chromosome 17 polysomy FISH signals were assessed by two independent assessors examining 30 non-overlapping nuclei for each tissue. The number of chromosome 17 signals and HER 2 signals was recorded in each case. The mean number of HER2 signals, CEP17 signals and the HER2/CEP17 ratio was calculated. HER2 gene amplification status was classified according to the ASCO/CAP criteria (9). The results
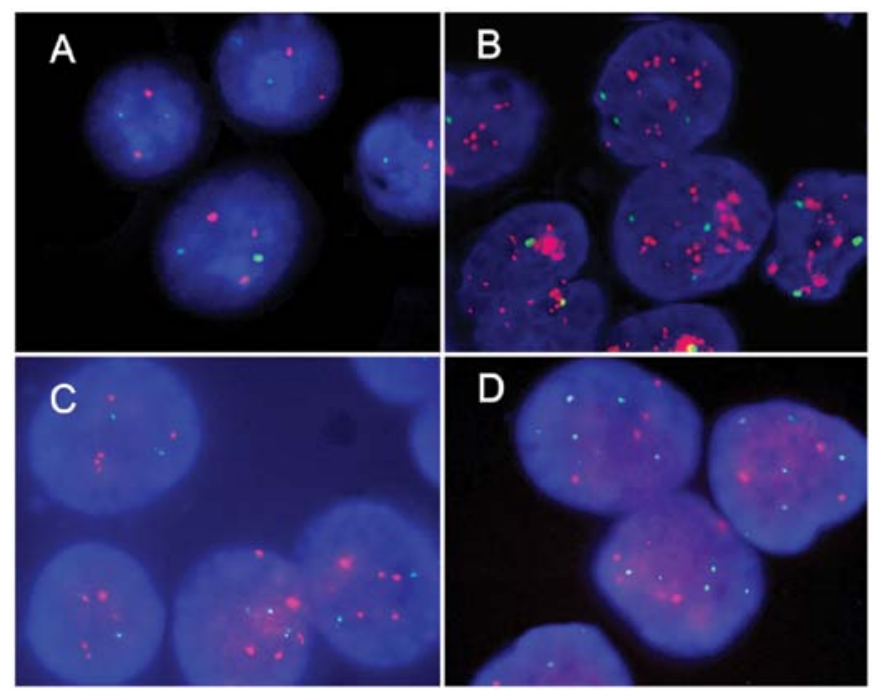

Figure 3. Representative micrographs of samples using TTFISH and WNFISH (A) Non-amplified HER2, HER2/CEP17 ratio <1.8; (B) amplified HER2, HER2/CEP17 ratio >2.2; (C) CEP17 non-polysomy, chromosome 17/nucleus $<2.6$; (D) CEP17 polysomy, chromosome $17 /$ nucleus $\geq 2.6$. TTFISH, thin tissue section FISH; WNFISH, whole nuclei FISH; HER2, human epidermal growth factor receptor 2 .

were graded based on the HER2/CEP17 ratios, as follows: negative HER2 gene amplification was defined as a HER2/ CEP17 ratio of $<1.8$. Equivocal $H E R 2$ gene amplification was defined as a HER2/CEP17 ratio between 1.8 and 2.2. Positive-HER2 gene amplification was defined as a HER2/ CEP17 ratio of $>2.2$.

Cases with an average chromosome 17 (CEP17) $\geq 2.6$ (27) per nucleus were considered polysomy.

Statistical analysis. The Student's t-test was used to compare the means of two variables for nominal data, which were shown as means \pm SD. McNemar and McNemar-Bowker tests were used to compare categorical variables. All reported $\mathrm{P}$-values were two-tailed. $\mathrm{P}<0.05$ was considered to indicate a statistically significant result.

Concordant data were determined from both TTFISH and WNFISH. The $\kappa$ statistic and associated $95 \%$ confidence intervals were used to measure the agreement among the two assays 
Table I. Correlation of HER2 and CEP17 copy numbers and HER2 ratio between TTFISH and WNFISH.

\begin{tabular}{lccrrr}
\hline Variables & TTFISH & WNFISH & T-value & P-value & 95\% CI \\
\hline HER2 copy number & $5.267 \pm 4.084$ & $5.497 \pm 3.996$ & -2.072 & 0.040 & $-0.450-0.010$ \\
CEP17 copy number & $2.361 \pm 1.100$ & $2.467 \pm 1.075$ & -3.628 & $<0.001$ & $-0.163-0.048$ \\
HER2 ratio & $2.144 \pm 1.140$ & $2.153 \pm 1.066$ & -0.335 & 0.738 & $-0.060-0.042$ \\
\hline
\end{tabular}

HER2, human epidermal growth factor receptor 2; TTFISH, thin tissue section FISH; WNFISH, whole nuclei FISH; CI, confidence interval.

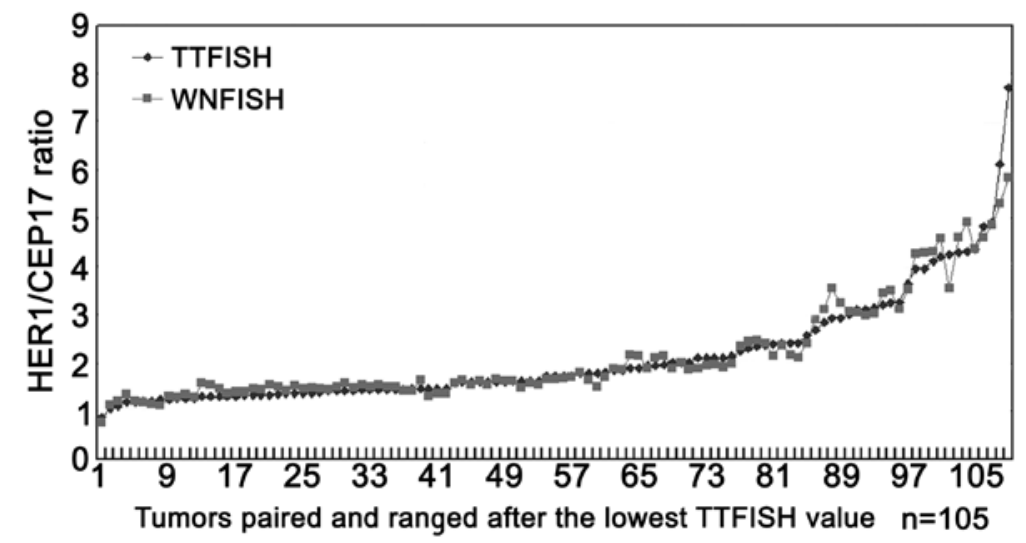

Figure 4. HER2/CEP17 ratios by TTFISH and WNFISH. HER2, human epidermal growth factor receptor 2; TTFISH, thin tissue section FISH; WNFISH, whole nuclei FISH.

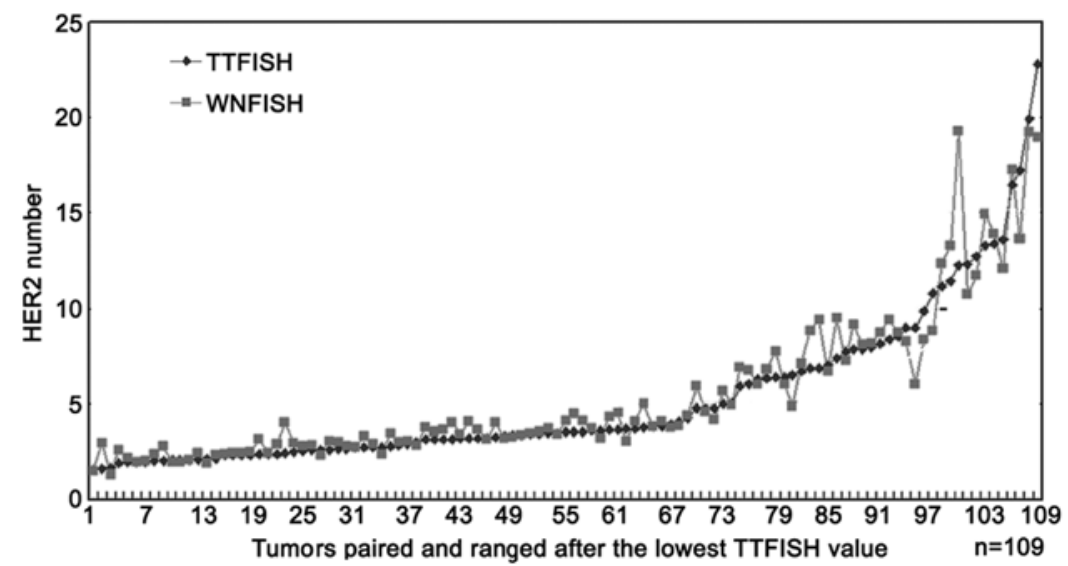

Figure 5. HER2 number by TTFISH and WNFISH. HER2, human epidermal growth factor receptor 2; TTFISH, thin tissue section FISH; WNFISH, whole nuclei FISH.

of the HER2/CEP17 ratio and CEP17 polysomy. The agreement was quantified with the $\kappa(\kappa)$ statistic, which evaluates inter-examiner reliability by eliminating agreement by chance. The $\kappa$ coefficient $>0.80$ indicated almost perfect agreement, values of 0.61-0.80 suggested substantial agreement, 0.41-0.60 moderate agreement, $0.21-0.40$ fair agreement, $>0-0.20$ slight agreement, and values of 0 suggested no agreement or a random association (28).

Correlations between the TTFISH and WNFISH CEP17 copy number, HER2 copy number and HER2 ratios were assessed by the Excel $\mathrm{X}, \mathrm{Y}$ plot to demonstrate the linear relationship between the two methods and to calculate the correlation coefficient (r).

\section{Results}

The CEP17 and HER2 gene copies, evaluated by TTFISH and WNFISH, were available for all 109 samples. Signals for HER 2 and chromosome 17 centromeres were clearly detected using the TTFISH and WNFISH methods. Separate signals were counted without difficulty for amplified, equivocal and non-amplified HER2 samples. Representative micrographs of the HER2 non-amplified, HER2 amplified, CEP17 nonpolysomy and CEP17 polysomy are shown in Fig. 3.

The HER 2 numbers, CEP17 copy numbers as well as $H E R 2$ ratios analyzed using the two methods are shown in Figs. 4-6. 


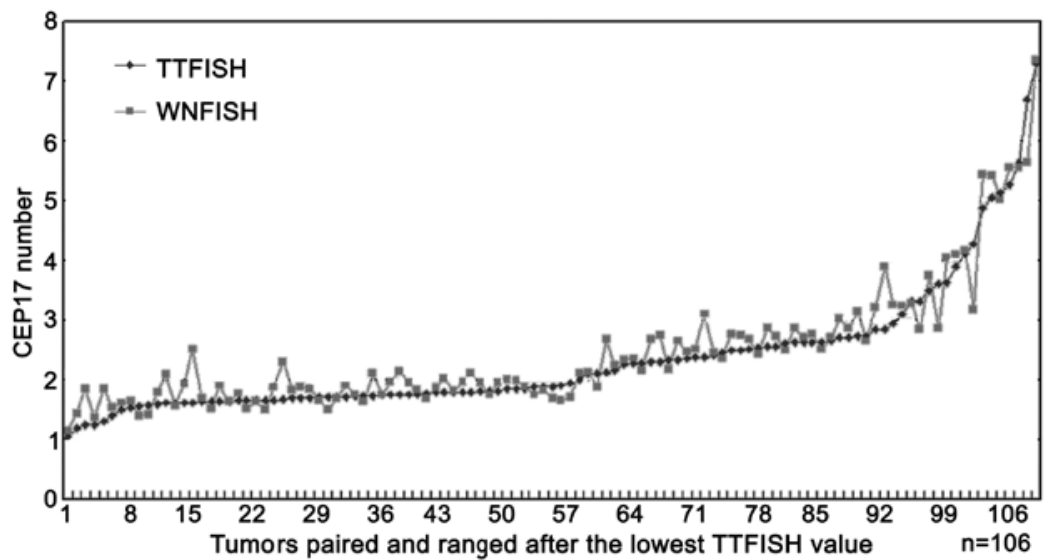

Figure 6. CEP17 number by WNFISH and TTFISH. TTFISH, thin tissue section FISH; WNFISH, whole nuclei FISH.

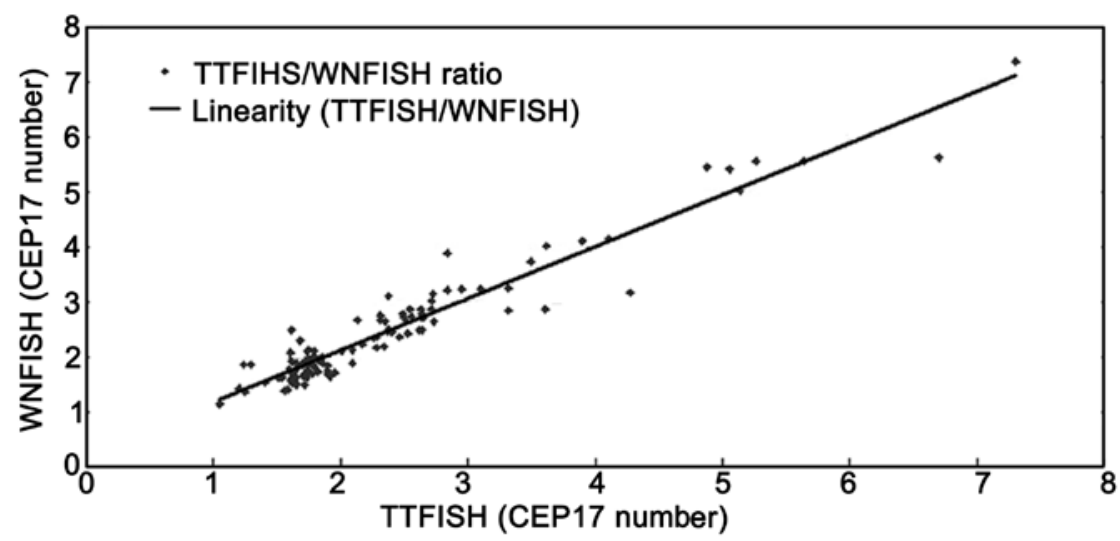

Figure 7. Correlation of CEP17 number between WNFISH and TTFISH. TTFISH, thin tissue section FISH; WNFISH, whole nuclei FISH.

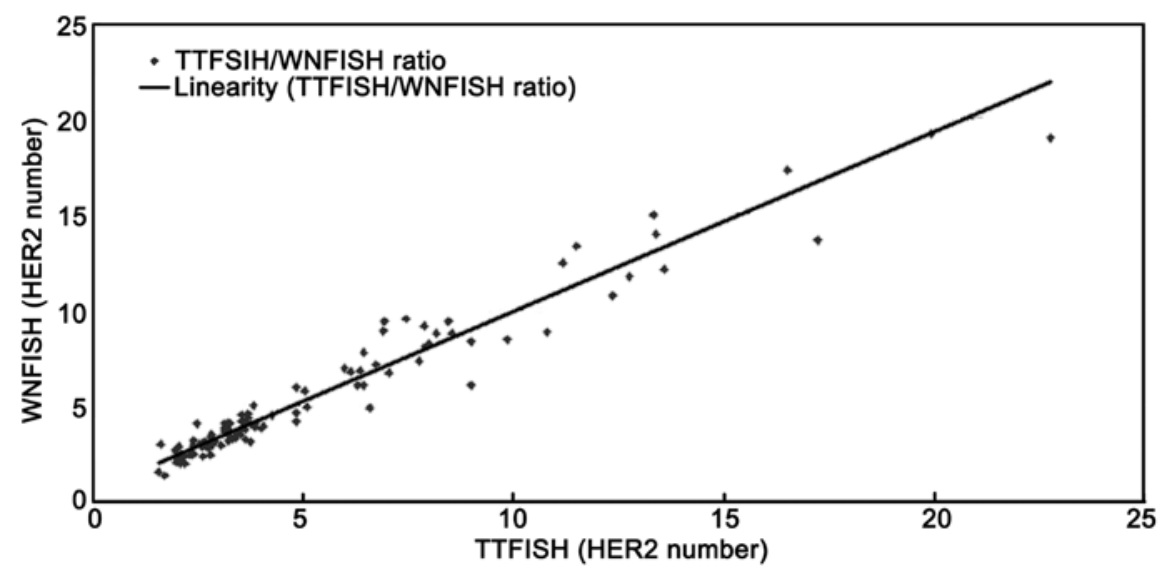

Figure 8. Correlation of HER2/CEP17 ratios between WNFISH and TTFISH. HER2, human epidermal growth factor receptor 2; TTFISH, thin tissue section FISH; WNFISH, whole nuclei FISH.

The mean copy number of Her 2 and CEP17 number detected by the two methods was $5.267 \pm 4.084$ vs. $5.497 \pm 3.996$ and $2.361 \pm 1.100$ vs. $2.467 \pm 1.075$. A significant difference was observed between the two methods in the detection of HER2 and CEP17 copy numbers $(\mathrm{P}=0.040$ and $<0.001)$ (Table I). The two methods showed a perfect correlation in detecting HER2 and CEP17 copy numbers (Figs. 7 and 8) with a correlation coefficient of $(r)=0.920$ and 0.924 . The $95 \%$ confidence intervals were $0.886-0.992$ and $0.888-0.991$, respectively.

The correlation between the HER2/CEP17 ratios obtained by the TTFISH and WNFISH methods was excellent (Fig. 9), with a correlation coefficient $(r)=0.946$ (95\% confidence interval, 0.868-0.951). No significant difference was observed between the two methods $(\mathrm{P}=0.738)$ (Table I). 


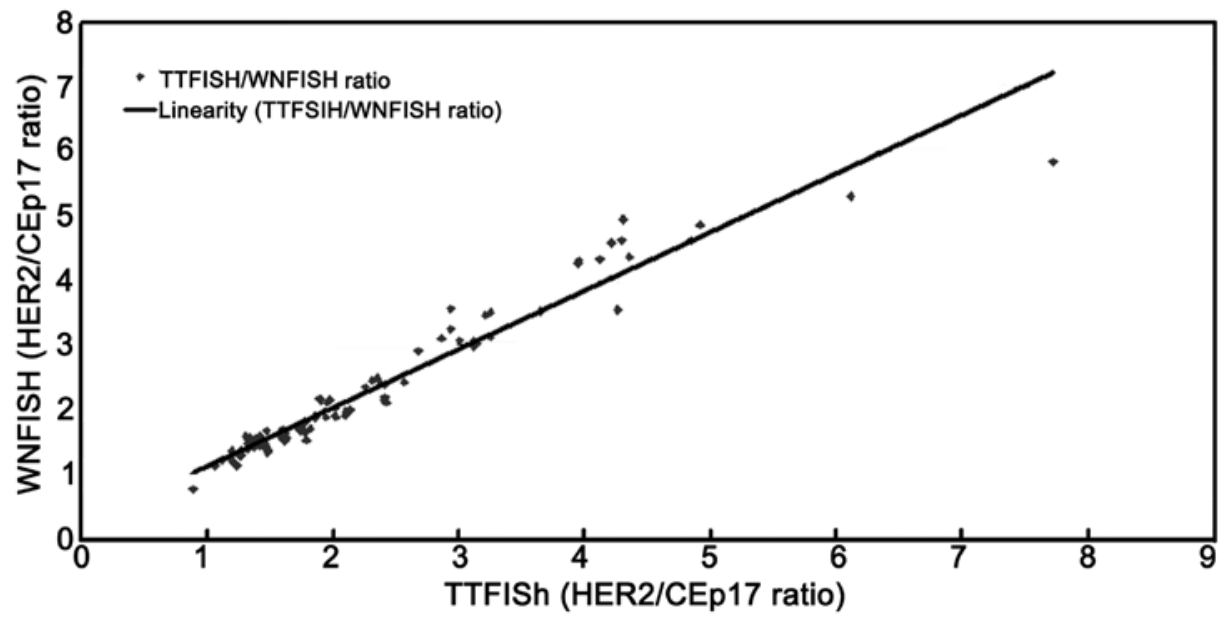

Figure 9. Correlation of HER2 number between WNFISH and TTFISH. HER2, human epidermal growth factor receptor 2; TTFISH, thin tissue section FISH; WNFISH, whole nuclei FISH.

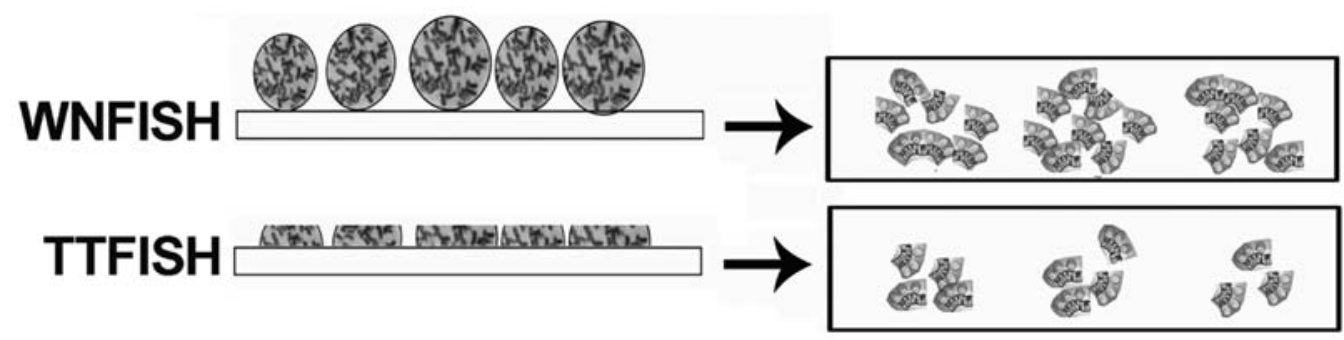

Figure 10. Summary of the results with WNFISH. All the chromosomes are retained and there are more CEP17 and HER2 signals. Concerning TTFISH, some chromosomes are lost, there are less CEP17 and HER2 signals. The sectioning process was associated with a similar probability of HER2 or CEP17 loss. Thus, the ratio of HER2/CEP13 is the same between WNFISH and TTFISH. WNFISH, whole nuclei FISH; TTFISH, thin tissue section FISH; HER2, human epidermal growth factor receptor 2; TTFISH, thin tissue section FISH.

Table II. HER2 amplification, TTFISH vs. WNFISH.

\begin{tabular}{lcccc}
\hline & \multicolumn{4}{c}{ WNFISH } \\
\cline { 2 - 5 } TTFISH & $\begin{array}{c}\text { Non- } \\
\text { amplified }^{\text {a }}\end{array}$ & Equivocal $^{\text {b }}$ & Amplified $^{c}$ & Total \\
\hline Non-amplified $^{\text {a }}$ & 59 & 1 & 0 & 60 \\
Equivocal $^{\mathrm{b}}$ & 1 & 15 & 0 & 16 \\
Amplified $^{\mathrm{c}}$ & 0 & 3 & 30 & 33 \\
Total & 60 & 19 & 30 & 109
\end{tabular}

Overall agreement: $0.945 \kappa$ coefficient $=0.922 \mathrm{McNemar}-$ Bowker test $\mathrm{P}=0.223 .{ }^{\mathrm{a}} \mathrm{HER} 2 / \mathrm{CEP} 17$ ratio $<1.8 ;{ }^{\mathrm{b}} \mathrm{HER} 2 / \mathrm{CEP} 17$ ratio between 1.8 and $2.2 ;{ }^{\mathrm{c}} H E R 2 / \mathrm{CEP} 17$ ratio $\geq 2.2$. HER2, human epidermal growth factor receptor 2; TTFISH, thin tissue section FISH; WNFISH, whole nuclei FISH.

Of the 109 cases, the WNFISH method revealed HER2 amplification (HER2 ratio >2.2) in 30 cases, equivocal (ratios from 1.8 to 2.2) in 19 cases and non-amplified HER2 (ratios $<1.8)$ in 60 cases. TTFISH method revealed HER2 amplification in 33 cases, equivocal in 16 cases and non-amplified $H E R 2$ in 60 cases. No significant difference occurred between the two methods (McNemar-Bowker test, $\mathrm{P}=0.223$ ).
Table III. Chromosome 17 polysomy, TTFISH vs. WNFISH.

\begin{tabular}{lccr}
\hline & \multicolumn{3}{c}{ WNFISH } \\
\cline { 2 - 4 } TTFISH & Non-polysomy $^{\mathrm{a}}$ & Polysomy $^{\mathrm{b}}$ & Total \\
\hline Non-polysomy $^{\mathrm{a}}$ & 70 & 10 & 80 \\
Polysomy $^{\mathrm{b}}$ & 2 & 27 & 29 \\
Total & 72 & 37 & 109 \\
\hline
\end{tabular}

Overall agreement: $0.890 \kappa$ coefficient $=0.741 \mathrm{McNemar}$ test $\mathrm{P}=0.039$. ${ }^{\mathrm{a}}$ Mean CEP17 number $<2.6$; ${ }^{\mathrm{b}}$ mean CEP17 number $\geq 2.6$. TTFISH, thin tissue section FISH; WNFISH, whole nuclei FISH.

The agreement between WNFISH and TTFISH was almost perfect: $95.41 \%(104 / 109), \kappa$ coefficient $=0.922$ (Table II). The WNFISH method detected CEP17 polysomy (CEP17 number $>2.6$ ) in 37 cases and non-polysomy (CEP17 number $<2.6$ ) in 72 cases. TTFISH method detected CEP17 polysomy in 29 cases and non-polysomy in 80 cases. A significant difference was observed between the two methods using the McNemar test $(\mathrm{P}=0.039)$. A substantial agreement existed between WNFISH and TTFISH: $89.0 \%(97 / 109) \kappa$ coefficient $=0.741$ (Table III). 


\section{Discussion}

TTFISH is routinely used to detect gene status in paraffinembedded breast cancer tissues. The average thickness of deparaffinized formalin fixed tissues was $4 \mu \mathrm{m}$, with $<6 \mu \mathrm{m}$ being the average diameter of a cell nucleus. Since only a portion of a given nucleus was observed in the sampling section, Tse et al (27) used a second chromosome 17 gene such as CEP17 to correct for possible truncation. The use of a reference gene abrogated the effect of variations in the section thickness. In addition, the use of the HER2:CEP17 ratio also rectified the increase in $H E R 2$ signals associated with cell proliferation during the G2 phase of the cell cycle. However, whether loss of genetic DNA during sectioning was associated with a detection bias should be investigated.

Whole intact nuclei extracted from paraffin-embedded tissues were used in FISH to detect the HER2 gene and CEP17 status. The approach enabled the preservation of genetic DNA in the experimental process. Compared with TTFISH, the present results have shown that the average copy numbers of the HER2 and CEP17 genes were higher with WNFISH compared to TTFISH. When chromosome 17 polysomy was evaluated according to the cut-off values reported in the literature, significantly more cases of chromosome 17 polysomy were identified by WNFISH than TTFISH ( 37 vs. $29, \mathrm{P}=0.039$ ). The result confirmed the loss of nuclear integrity and genetic materials during the sectioning of FFPE tissue blocks. No statistical difference was observed between the two methods in the detection of HER2/CEP17 ratio ( $\mathrm{P}=0.738)$. According to ASCO/CAP standards of $H E R 2$ gene amplification, the concordance rate of the two methods was $95.41 \%$, with a correlation coefficient of 0.922 . The sectioning process was associated with a similar probability of HER 2 or CEP17 loss. The HER2/ CEP17 ratio was not affected after calculation of various nuclear signals (Fig. 10). As a result, TTFISH and WNFISH were comparable in the detection of the HER2/CEP17 ratio.

Nuclei extracted from paraffin-embedded tissues contain breast cancer cells as well as normal breast and stromal cells. Contrary to expectations, the results of our study show an increased CEP17 copy number obtained by WNFISH as compared to TTFISH, suggesting that thin tissue sections caused the loss of cell integrity, resulting in biased analyses with FISH.

The widespread use of TTFISH in the clinical and research fields has lowered expectations of high standards and accuracy. Apparently, the complexity of the experimental steps in WNFISH may restrict its application. However, in the present study WNFISH was an effective substitute for TTFISH, and a sensitive and prognostic tool in targeted therapy.

The present study demonstrated a linear correlation between CEP17 and HER2 copy number. As a result, we estimated WNFISH results by analyzing TTFISH results. Irrespective of the method employed, a reasonable cut-off value was critical for accurate interpretation of the data.

CEP17 signals represent tumors exhibiting chromosome 17 polysomy. The most direct method uses an average signal count of CEP17, in which levels above a cut-off score are considered indicative of polysomy 17. Findings of a previous study show that, $>1.86$ (29) to three CEP17 signals/cell were indicative of polysomy (23).
In conclusion, detection of chromosome 17 polysomy in breast cancer with fluorescence in situ hybridization using thin tissue sections may cause the loss of CEP17 and HER2 signals.

\section{Acknowledgements}

This study was supported by the Natural Science Foundation of Liaoning Province (grant no. 2013020217).

\section{References}

1. Gschwind A, Fischer OM and Ullrich A: The discovery of receptor tyrosine kinases: targets for cancer therapy. Nat Rev Cancer 4: 361-370, 2004.

2. Lal P, Salazar PA, Hudis CA, Ladanyi M and Chen B: HER-2 testing in breast cancer using immunohistochemical analysis and fluorescence in situ hybridization: a single-institution experience of 2,279 cases and comparison of dual-color and single-color scoring. Am J Clin Pathol 121: 631-636, 2004.

3. Owens MA, Horten BC and Da Silva MM: HER2 amplification ratios by fluorescence in situ hybridization and correlation with immunohistochemistry in a cohort of 6556 breast cancer tissues. Clin Breast Cancer 5: 63-69, 2004.

4. Yaziji H, Goldstein LC, Barry TS, et al: HER-2 testing in breast cancer using parallel tissue-based methods. JAMA 291: 1972-1977, 2004.

5. Baselga J, Bradbury I, Eidtmann H, et al: Lapatinib with trastuzumab for HER 2-positive early breast cancer (NeoALTTO): a randomised, open-label, multicentre, phase 3 trial. Lancet 379: 633-640, 2012.

6. Valabrega G, Capellero S, Cavalloni G, et al: HER2-positive breast cancer cells resistant to trastuzumab and lapatinib lose reliance upon HER 2 and are sensitive to the multitargeted kinase inhibitor sorafenib. Breast Cancer Res Treat 130: 29-40, 2011.

7. Carr JA, Havstad S, Zarbo RJ, Divine G, Mackowiak P and Velanovich V: The association of HER-2/neu amplification with breast cancer recurrence. Arch Surg 135: 1469-1474, 2000.

8. Arteaga CL, Sliwkowski MX, Osborne CK, Perez EA, Puglisi F and Gianni L: Treatment of HER2-positive breast cancer: current status and future perspectives. Nat Rev Clin Oncol 9: 16-32, 2012.

9. Wolff AC, Hammond ME, Schwartz JN, et al: American Society of Clinical Oncology/College of American Pathologists guideline recommendations for human epidermal growth factor receptor 2 testing in breast cancer. J Clin Oncol 25: 118-145, 2007.

10. Ohlschlegel C, Zahel K, Kradolfer D, Hell M and Jochum W: HER 2 genetic heterogeneity in breast carcinoma. J Clin Pathol 64: 1112-1116, 2011.

11. Dal Lago L, Durbecq V, Desmedt C, et al: Correction for chromosome-17 is critical for the determination of true Her-2/neu gene amplification status in breast cancer. Mol Cancer Ther 5: 2572-2579, 2006.

12. Ma Y, Lespagnard L, Durbecq V, et al: Polysomy 17 in $H E R-2 / n e u$ status elaboration in breast cancer: effect on daily practice. Clin Cancer Res 11: 4393-4399, 2005.

13. Reddy JC, Reimann JD, Anderson SM and Klein PM: Concordance between central and local laboratory HER2 testing from a community-based clinical study. Clin Breast Cancer 7: 153-157, 2006.

14. Reinholz MM, Bruzek AK, Visscher DW, et al: Breast cancer and aneusomy 17: implications for carcinogenesis and therapeutic response. Lancet Oncol 10: 267-277, 2009.

15. Zhang $\mathrm{W}$ and $\mathrm{Yu} \mathrm{Y}$ : The important molecular markers on chromosome 17 and their clinical impact in breast cancer. Int J Mol Sci 12: 5672-5683, 2011.

16. Downs-Kelly E, Yoder BJ, Stoler M, et al: The influence of polysomy 17 on HER2 gene and protein expression in adenocarcinoma of the breast: a fluorescent in situ hybridization, immunohistochemical, and isotopic mRNA in situ hybridization study. Am J Surg Pathol 29: 1221-1227, 2005.

17. Bose S, Mohammed M, Shintaku P and Rao PN: Her-2/neu gene amplification in low to moderately expressing breast cancers: possible role of chromosome $17 / \mathrm{Her}-2 /$ neu polysomy. Breast J 7: 337-344, 2001.

18. Farabegoli F, Ceccarelli C, Santini D, et al: c-erbB-2 overexpression in amplified and non-amplified breast carcinoma samples. Int J Cancer 84: 273-277, 1999. 
19. Pritchard KI, Munro A, O'Malley FP, et al: Chromosome 17 centromere (CEP17) duplication as a predictor of anthracycline response: evidence from the NCIC Clinical Trials Group (NCIC CTG) MA.5 Trial. Breast Cancer Res Treat 131: 541-551, 2012

20. Lal P, Salazar PA, Ladanyi M and Chen B: Impact of polysomy 17 on HER-2/neu immunohistochemistry in breast carcinomas without HER-2/neu gene amplification. J Mol Diagn 5: 155-159, 2003.

21. Varshney D, Zhou YY, Geller SA and Alsabeh R: Determination of HER-2 status and chromosome 17 polysomy in breast carcinomas comparing HercepTest and PathVysion FISH assay. Am J Clin Pathol 121: 70-77, 2004.

22. Rosenberg CL: Polysomy 17 and HER-2 amplification: true, true, and unrelated. J Clin Oncol 26: 4856-4858, 2008.

23. Vanden Bempt I, Van Loo P, Drijkoningen M, et al: Polysomy 17 in breast cancer: clinicopathologic significance and impact on HER-2 testing. J Clin Oncol 26: 4869-4874, 2008.

24. Pritchard KI, Shepherd LE, O'Malley FP, et al: HER2 and responsiveness of breast cancer to adjuvant chemotherapy. $\mathrm{N}$ Engl J Med 354: 2103-2111, 2006.
25. Shah SS, Wang Y, Tull J and Zhang S: Effect of high copy number of HER2 associated with polysomy 17 on HER2 protein expression in invasive breast carcinoma. Diagn Mol Pathol 18: 30-33, 2009.

26. Kouvaras E, Papandreou CN, Daliani DD, Athanasiadis A and Koukoulis GK: Comparative study of spatial localization of HER-2 and CEP17 signals and of HER-2/CEP17 ratios, in 'thin' and 'thick' tissue sections. Breast 21: 34-39, 2012.

27. Tse $\mathrm{CH}$, Hwang HC, Goldstein LC, et al: Determining true HER2 gene status in breast cancers with polysomy by using alternative chromosome 17 reference genes: implications for anti-HER2 targeted therapy. J Clin Oncol 29: 4168-4174, 2011.

28. JR L and GG K: A one-way components of variance model for categorical data. Biometrics 334: 671-679, 1977.

29. Watters AD, Going JJ, Cooke TG and Bartlett JM: Chromosome 17 aneusomy is associated with poor prognostic factors in invasive breast carcinoma. Breast Cancer Res Treat 77: 109-114, 2003. 